\title{
INVESTIGATIONS AND COMPARISON OF THERMOGRAVIMETRIC AND DIFFERENTIAL THERMAL ANALYSIS OF MOLYBDENUM TRIOXIDE AND ITS NANOCOMPOSITE POWDERS
}

\author{
T. VIJAYA KUMAR ${ }^{1} \&$ K.V.RAMANA ${ }^{2}$ \\ ${ }^{\text {I} A s s o c i a t e ~ P r o f e s s o r, ~ D e p a r t m e n t ~ o f ~ M e c h a n i c a l ~ E n g i n e e r i n g, ~ K L E F, ~ V a d d e s w a r a m ~}$ \\ ${ }^{2}$ Professor, Department of Mechanical Engineering, KLEF, Vaddeswaram
}

\section{ABSTRACT}

The objective of the present work was to investigate and compare thermo gravimetric analysis (TGA) and differential thermal analysis (DTA) of $\mathrm{MoO}_{3}, \mathrm{MoO}_{3}-\mathrm{CuO}, \mathrm{MoO}_{3}-\mathrm{V} 2 \mathrm{O} 5$ and $\mathrm{MoO}_{3}-\mathrm{TiO}_{2}$ composite nano powders using ball synthesis techniques at different intervals of time. The synthesized composite nanopowders were characterized by spectroscopic characteristics such as Powder X Ray diffraction (PXRD), Scaning Electron Microscopy (SEM), Electron Dispersive X Ray Spectroscopy (EDS), Thermo gravimetric Analysis (TGA) and Differential Thermal Analysis (DTA). The orthorhombic phase of $\mathrm{V}_{2} \mathrm{O}_{5}, \mathrm{MoO}_{3}, \mathrm{TiO}_{2}$ and monoclinic phase of CuO were revealed by X-Ray peak profile demonstrates. $\mathrm{MoO}_{3}, \mathrm{MoO}_{3}-\mathrm{CuO}$ and $\mathrm{MoO}_{3}-\mathrm{TiO}_{2} \mathrm{SEM}$ photographs Indicate the unusual particle forms and $\mathrm{MoO}_{3}-\mathrm{V}_{2} \mathrm{O}_{5}$, show abnormal circular structures of vanadium flakes deposits. The EDS spectrum confirms the presence of the elements of the prepared samples. From the thermal analysis it has observed that thermo gravimetric and differential thermal analysis plots for $\mathrm{MoO}_{3}-\mathrm{CuO}$ nanocomposite powders shows high thermal stability up to $7100 \mathrm{C}$ as there is a negligible weight loss which gives the better results. The as-synthesized nanocomposites can also be used at a high temperature as stable lubricants.

KEYWORDS: $\mathrm{MoO}_{3}$, Ball Milling, Nanocomposite, TGA and DTA

Received: Jun 10, 2020; Accepted: Jun 30, 2020; Published: Aug 04, 2020; Paper Id.: IJMPERDJUN2020609

\section{INTRODUCTION}

Because of their interesting applications as catalysts, transitional metal oxides as new class of research materials, and sensors as well as photchromatic appliances. Molybdenum oxide $\left(\mathrm{MoO}_{3}\right)$ is desirable among such products due to its structural and optical properties [1-2]. Nanotechnology also offers a wide range of tribological research. In general, molybdenum oxide exhibit allotropy (exist as 3 distinct phase structures) as stable orthorhombic $\left(\alpha-\mathrm{MoO}_{3}\right)$, Monoclinic $\left(\beta-\mathrm{MoO}_{3}\right)$ and Hexagonal $\left(\mathrm{h}-\mathrm{MoO}_{3}\right)$ [3]. It has a significant area of applications such as smart material (photochromatic material), lubricants and catalysts. $\mathrm{MoO}_{3}$ is a solid lubricant because its coefficient of friction at high temperatures of approximately $645^{\circ} \mathrm{C}$ is excellent. $\mathrm{MoO}_{3}$ has been analyzed for friction and wear at high temperatures with aluminum bronze. Significant results were achieved. MoO3-bases nano for their superior tribological properties, the composites $\mathrm{MoO} 3-\mathrm{PbO}$ and $\mathrm{MoO} 3-\mathrm{ZnO}$ are studied at high temperatures. $\mathrm{MoO} 3 \mathrm{has}$ many applications due to its special thermal, mechanical, magnetic or electrical properties in addition to its frictional properties [4-6].

Due to their significant friction reduction properties, copper oxide nano powders can also be used as solid (stable) lubricants. Most lamellar / layered solid lubricants fail in open air and at elevated temperatures of above 
$495{ }^{\circ} \mathrm{C}$ for lubrication applications as they become oxides [7]. A mixed oxide can be used for improved friction outputs at various high temperatures such as $\mathrm{MoO}_{3} / \mathrm{CuO}$ alloy or composite [8-9].Titanium dioxide $\left(\mathrm{TiO}_{2}\right)$ is widely used as an opacifier in lubricants and lubricant additives and other applications, and for its ultraviolet - resistant properties where the powder disperses light, unlike organic ultraviolet absorbers, and reduces ultraviolet damage, mainly due to the higher particulate matter [10-11]. Vanadium Pentoxide is a semi-conductive material which, in addition to solid state chemistry and material science, has a lot of interest in tribology [12]. Vanadium catalysts - based on the availability of multiple Oxidation States and therefore the potentially interesting vanado catalysts are known to be effective in oxidation chemistry[13-15].The method of ball milling, chemical and physical vapor deposition, sol - gel method, etc., are different methods of synthesis to obtain nanocomposites. The aim of the present work was to compare thermo gravimetic analysis and differential thermal analysis of various molybdenum trioxide nanocomposites and its allied mixtures synthesized by the process of planetary ball milling [16].

\section{MATERIALS AND METHODOLOGY}

Molybdenum tri oxide, Vanadium Pentoxide, Copper Oxide and Titanium dioxide were procured from Merk chemicals, Mumbai. The chemical reagents are analytical and used without further purification. The reagents (chemical) used in the synthesis are with purity above $99.5 \%$. Oxides of Molybdenum, Titanium, Copper and Vanadium powders of mean size 10 microns were selected. Weight ratios of oxides of Molybdenum and copper as 2.3:1 \& 3.3:1, 1:1 ratio for oxides of Molybdenum, Copper and Vanadium were homogeneously mixed separately [17-18]. As shown in Fig.1, mechanical synthesis was done with a 1:10 powder / ball ratio. The milling was performed for two hours with intervals of five minutes for every twenty minutes and a rotational velocity of $250 \mathrm{rpm}$ respectively. A synthesis process is made from the ball mill of $100 \mathrm{ml}$ bottle (vial) and Zirconium balls [19]. The mixtures obtained were taken in a crucible and calcinated at $250{ }^{\circ} \mathrm{C}$ in the air for 2 hours.

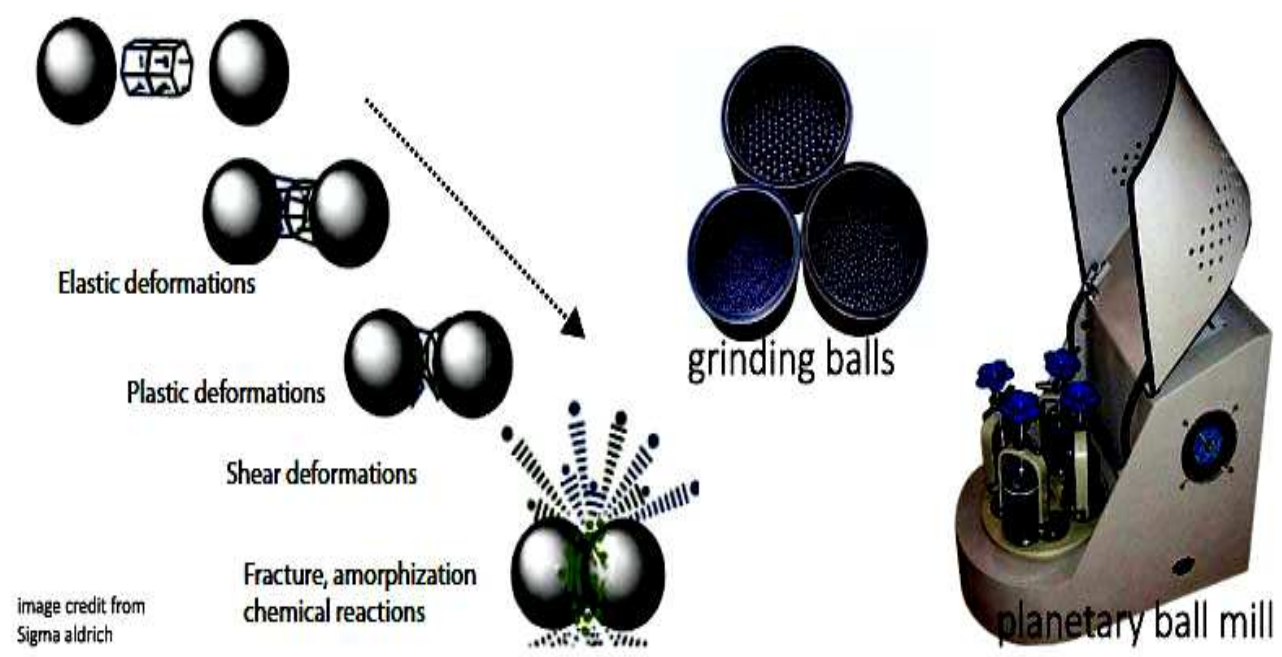

Figure 1: Planetary Ball Milling Equipment. 


\section{RESULT AND DISCUSSION}

\section{Charaterisation}

\section{Powder X-Ray Diffraction Patterns}

Powder X-Ray diffraction (XRD) patterns of $\mathrm{MoO}_{3}, \mathrm{MoO}_{3}-\mathrm{CuO}, \mathrm{MoO}_{3}-\mathrm{TiO}_{2}$ and $\mathrm{MoO}_{3}-\mathrm{V}_{2} \mathrm{O}_{5}$ nanocomposite powders were carried on a XPert Pro-diffractometer with $\mathrm{Cu}-\mathrm{K}_{\alpha}$ radiation $\left(\lambda=1.56 \mathrm{~A}^{\circ}\right)$. The measurements were taken at room temperature from $10^{\circ}$ to $80^{\circ}$ on position $(2 \theta)$ with a step size of $0.1 \circ$ in $50 \mathrm{KeV}, 10 \mathrm{mV}$ current[20-21]. Various XRD patterns are as shown in Fig.2 to Fig.5.

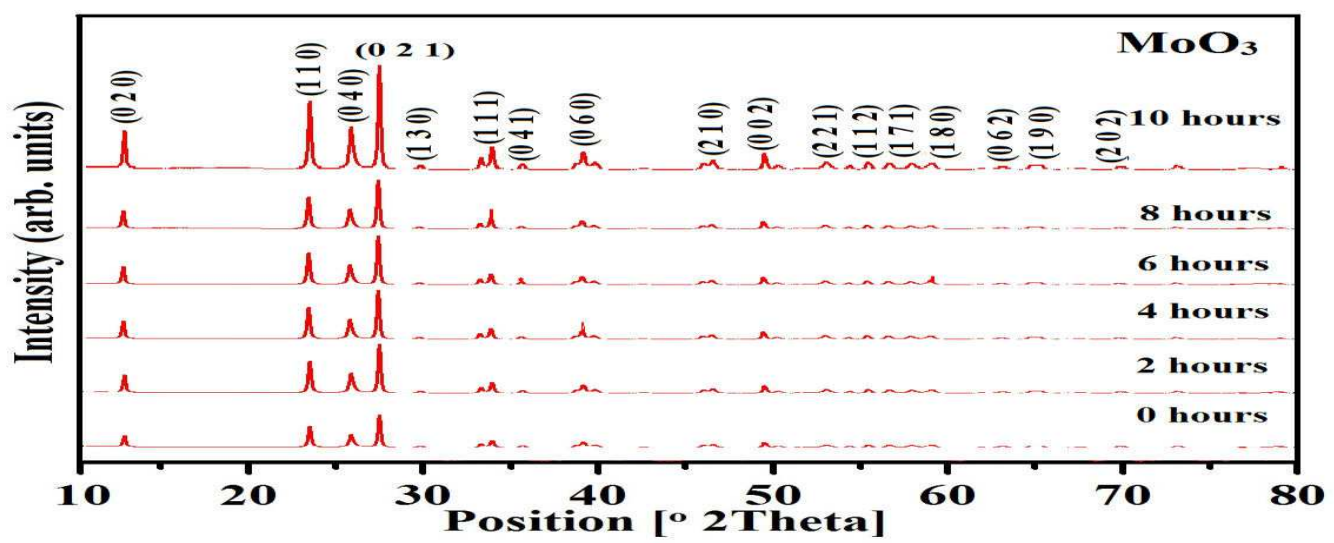

Figure 2: X-Ray Diffraction Peaks of Ball Milled $\mathrm{MoO}_{3}$ Nano Powders.

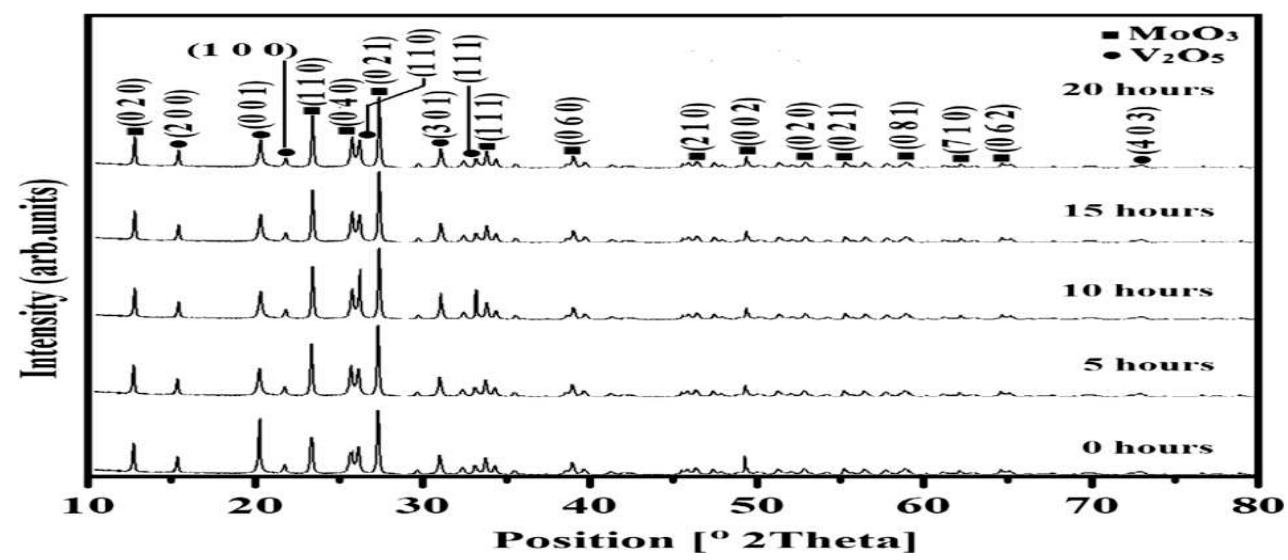

Figure 3: X-Ray Diffraction Peaks of Ball Milled $\mathrm{MoO}_{3}-\mathrm{V}_{2} \mathrm{O}_{5}$ Composite Nano Powders.

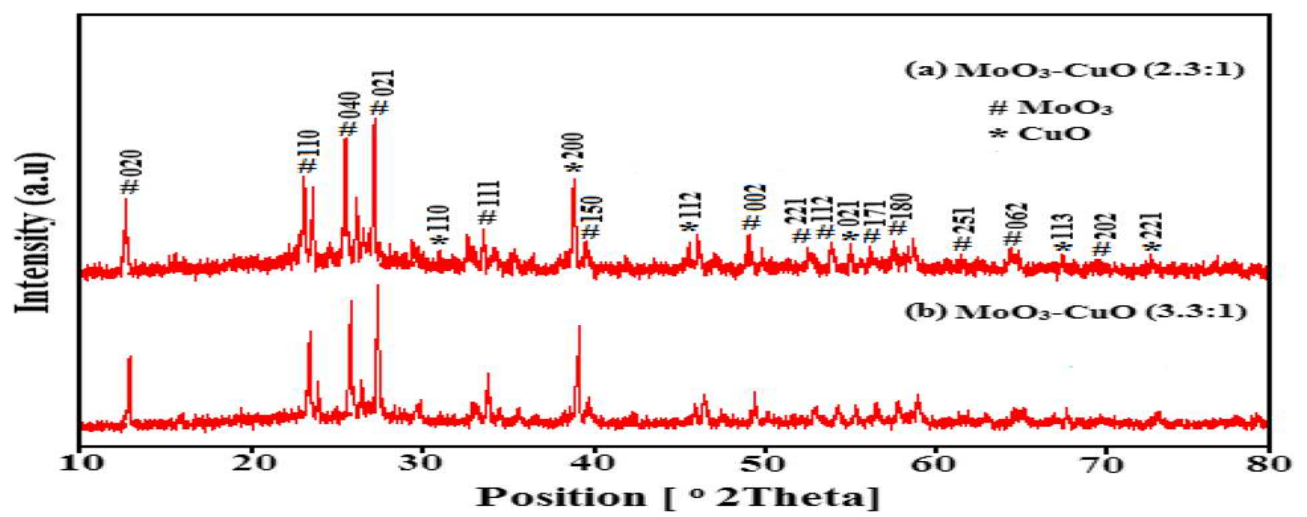

Figure 4: X-Ray Diffraction Peaks of Ball Milled $\mathrm{MoO}_{3}-\mathrm{CuO}$ Composite Nano Powders. 


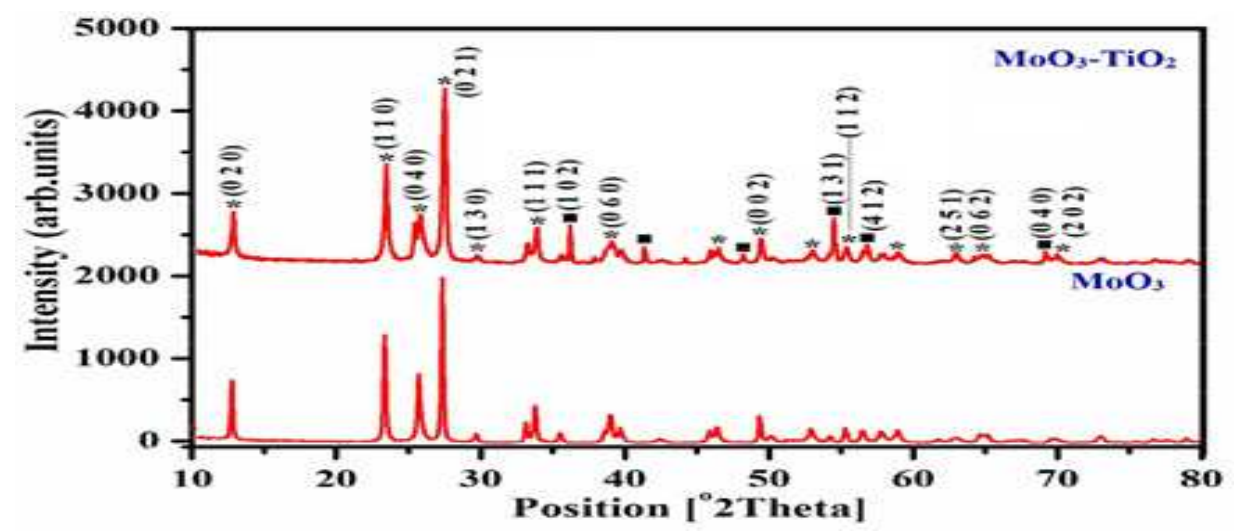

Figure 5: X-Ray Diffraction Peaks of Ball Milled $\mathrm{MoO}_{3}$-TiO2 Composite Nano Powders.

Synthesised nano powder diffraction peaks are well-suited with regular JCPDS data diffraction files [22]. With respect to the milling time, no variation in phase structures are observed.

\section{Scanning Electron Microscopy with EDS Patterns}

SEM micrographs were taken from a CarlZeiss SEM and EDAX pictures were taken from ZESS EVO20.
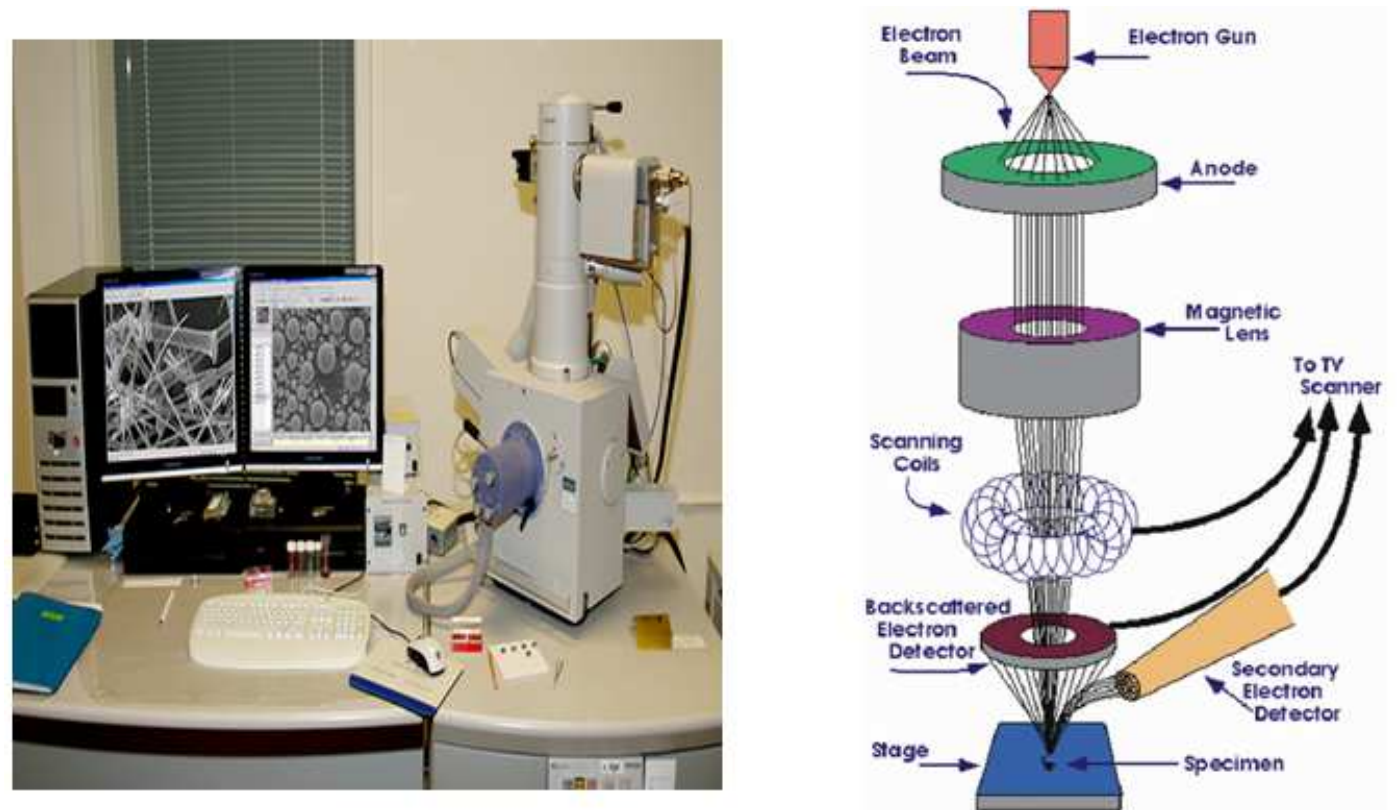

Figure 6: Schematic Representation of the Basic SEM Components.

SEM equipment morphology studies as shown on Fig.6 are observed in SEM pictures [23]. Scanning electron microscopy is a significant method for the topography of sample characterization and provides information on the mechanism of growth, shape and dimensions of particles. Various SEM images of $\mathrm{MoO}_{3}, \mathrm{MoO}_{3}-\mathrm{CuO}, \mathrm{MoO}_{3}-\mathrm{TiO}_{2}$ and $\mathrm{MoO}_{3}-\mathrm{V}_{2} \mathrm{O}_{5}$ nanocomposite powders are as shown below from Fig.7 to Fig.11[24-25]. 

Molybdenum Trioxide and Its Nanocomposite Powders
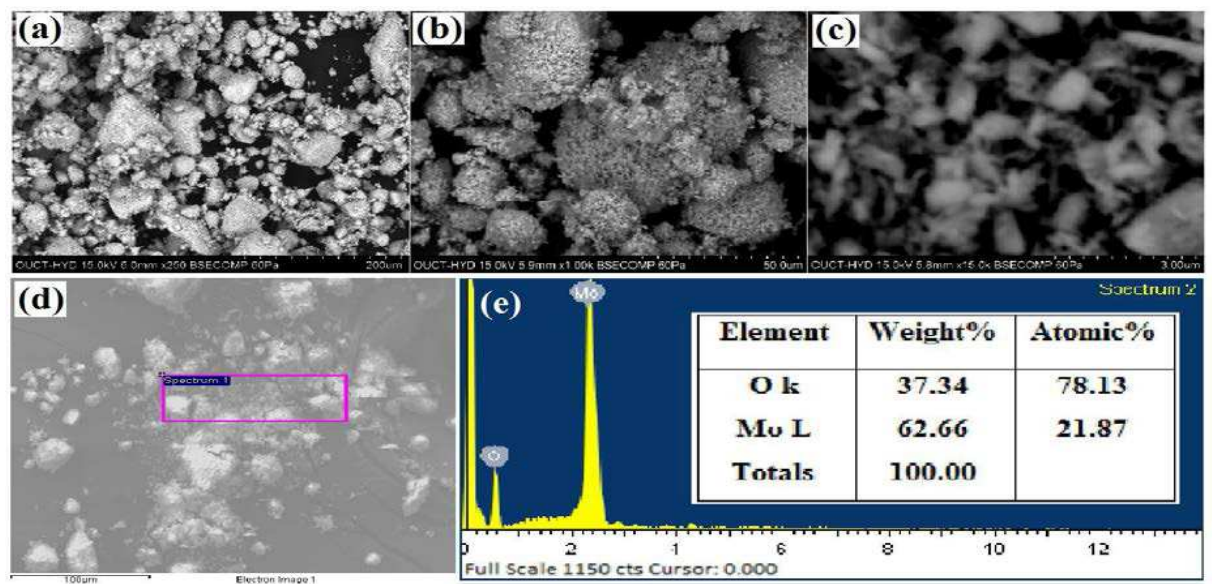

Figure 7: Scanning Electron Microscope Images $(a, b, c)$ and EDS Pattern(d and e) of $\mathrm{MoO}_{3}$ Composite Powders.

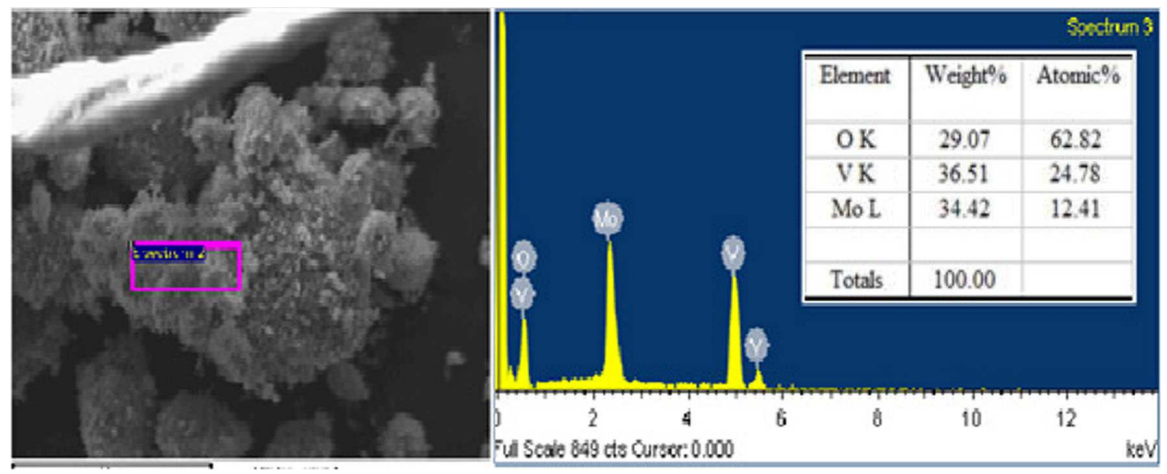

Figure 8: SEM Images and EDS Pattern of $\mathrm{MoO}_{3}-\mathrm{V}_{2} \mathrm{O}_{5}$ Composite Nano Particles.
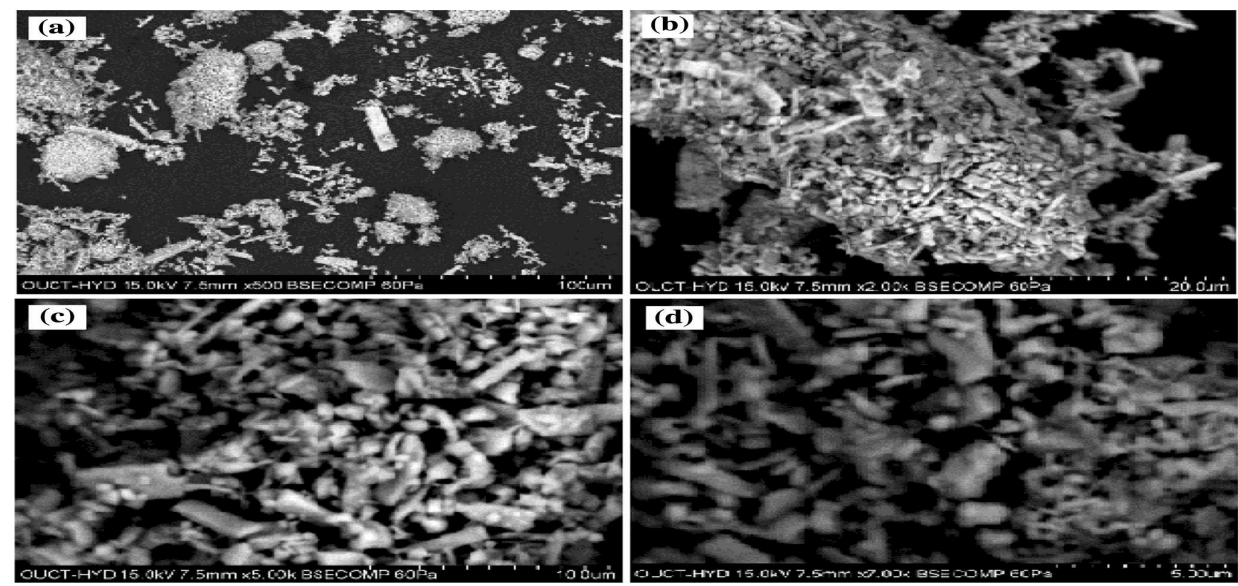

Figure 9: (a, b, c, d) SEM Images of 2.3:1 and 3.3:1 $\mathrm{MoO}_{3}-\mathrm{CuO}$ Composite Nano Particles. 


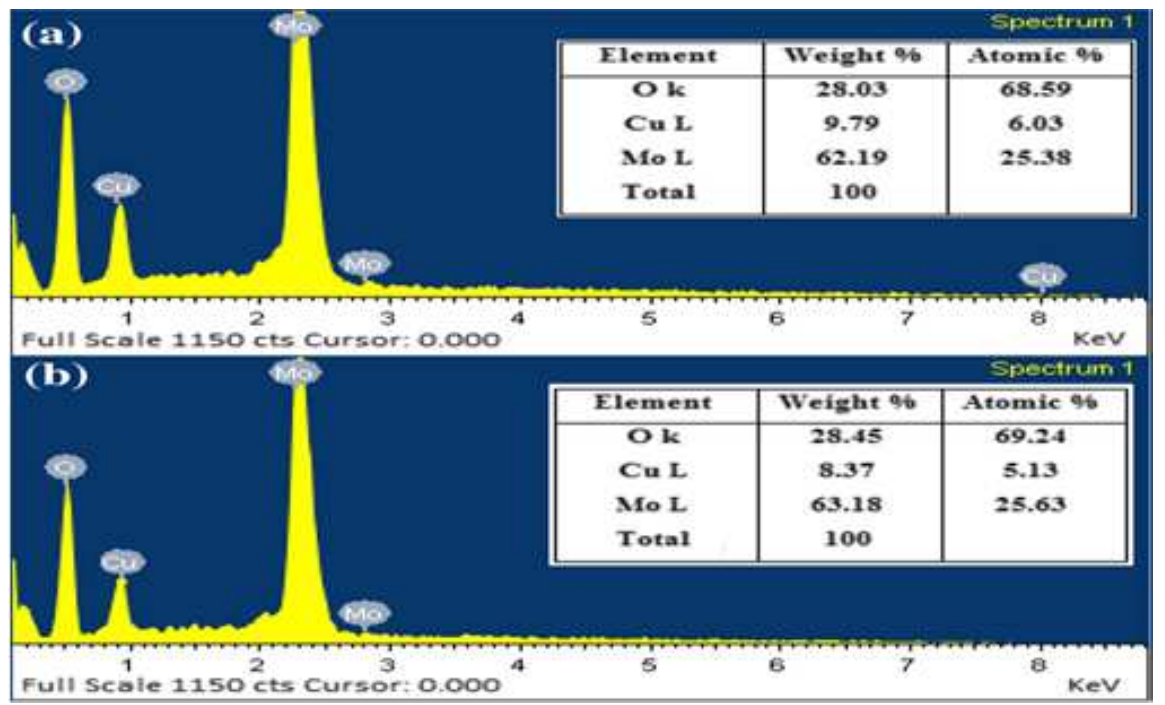

Figure 10: Electron Dispersive Patterns of a) 2.3:1 and b) 3.3:1 $\mathrm{MoO}_{3}-\mathrm{CuO}$ Composite Nano Particles.
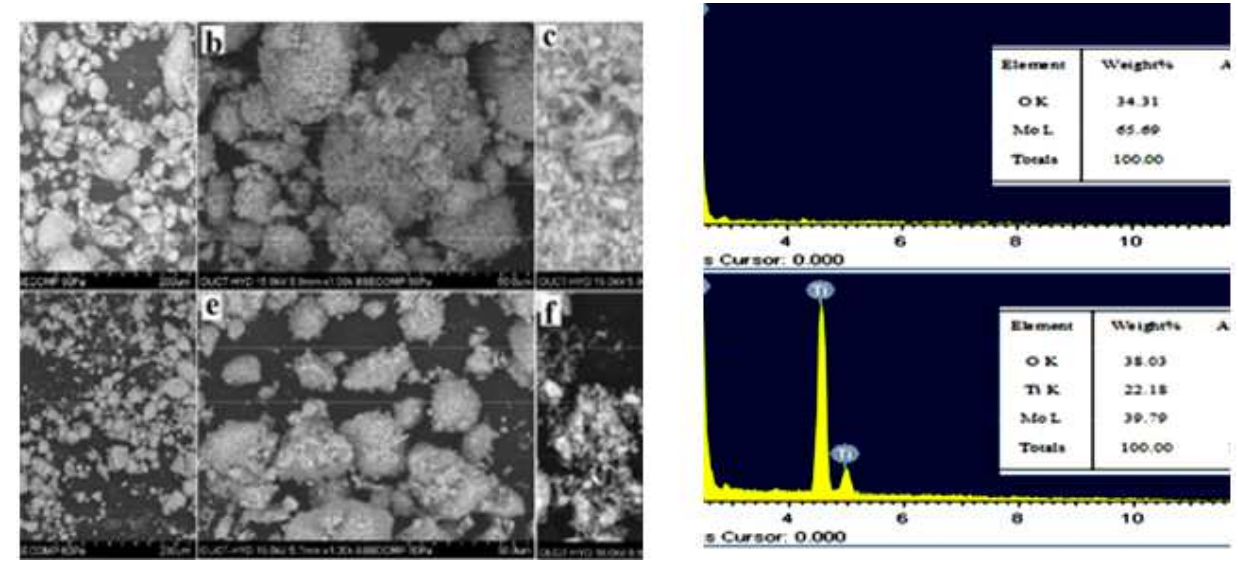

Figure 11: SEM Images and EDS Patterns of $\mathrm{MoO}_{3}-\mathrm{TiO}_{2}$ Composite Nano-Powders.

Morphology obtained from $\mathrm{MoO}_{3}, \mathrm{MoO}_{3}-\mathrm{CuO}, \mathrm{MoO}_{3}-\mathrm{TiO}_{2} \mathrm{SEM}$ pictures confirm irregular forming particle size and display irregular spherical shaped structures and in $\mathrm{MoO}_{3}-\mathrm{V}_{2} \mathrm{O}_{5}$ deposited with vanadium flakes[26, 30,31]. The EDS spectrum confirms the fact that the samples prepared are constituent elements.

\section{Thermogravimetric and Differential Thermal Analysis}

Thermogravimetric analysis (TGA) and Differential Thermal analysis (DTA) play a critical role in understanding the thermal stability and relative loss of weight of the material [27-28]. The analysis are performed under nitrogen atmosphere of $25 \mathrm{~cm}^{3} \mathrm{~min}^{-1}$ at a ramp rate of $5{ }^{\circ} \mathrm{C} \mathrm{m^{-1 }}$ using TGA/DTA instruments SDT Q500.The sample weighs around 10 milligrams, the thermogravimetric and differential thermal analysis[29-30] plots of $\mathrm{MoO}_{3}, \mathrm{MoO}_{3}-\mathrm{CuO}_{1} \mathrm{MoO}_{3}-\mathrm{TiO}_{2}$ and $\mathrm{MoO}_{3}-\mathrm{V}_{2} \mathrm{O}_{5}$ are as shown in the Fig.12 to Fig.15(a,b). 


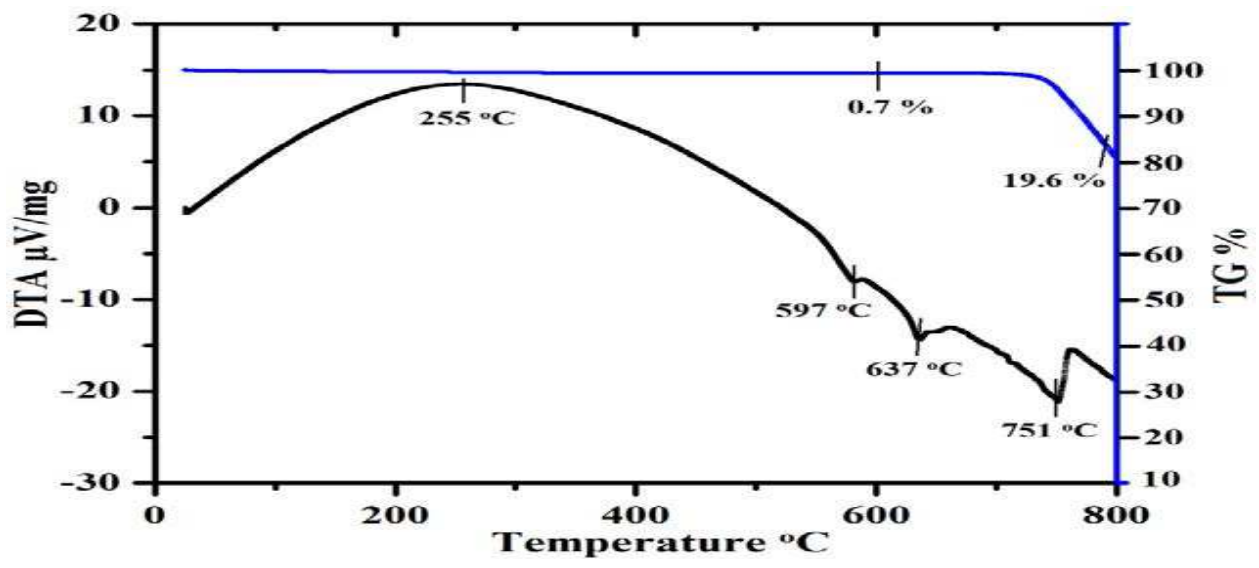

Figure 12: Thermogravimetric and Differential Thermal Analysis Plots of $\mathrm{MoO}_{3}$ Nano Particles.

$\mathrm{MoO}_{3}$ nano powders demonstrate excellent thermal stability up to $638^{0} \mathrm{C}$ with a marginal 0.75 percent weight loss

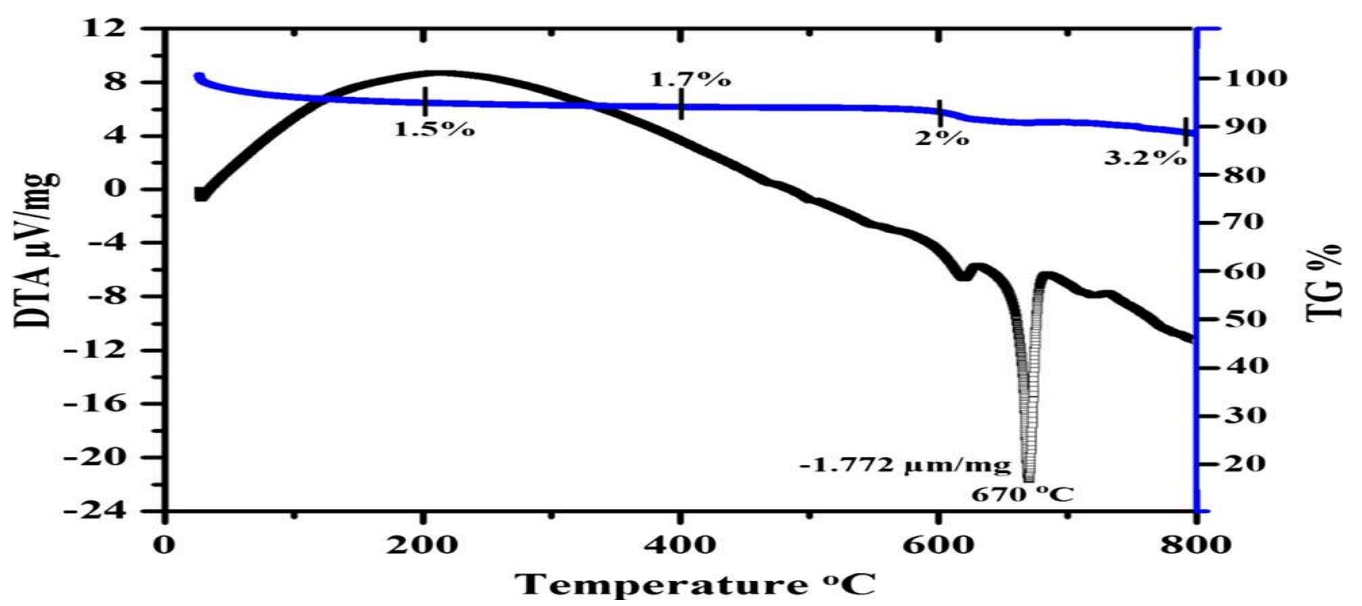

Figure 13: Thermogravimetric and Differential Thermal Plots of $\mathrm{MoO}_{3}-\mathrm{V}_{2} \mathrm{O}_{5}$ Nano Particles.

$\mathrm{MoO}_{3}-\mathrm{V}_{2} \mathrm{O}_{5}$ shows a negligible weight loss of $2.3 \%$ with an excellent thermal stability at $672^{0} \mathrm{c}$.

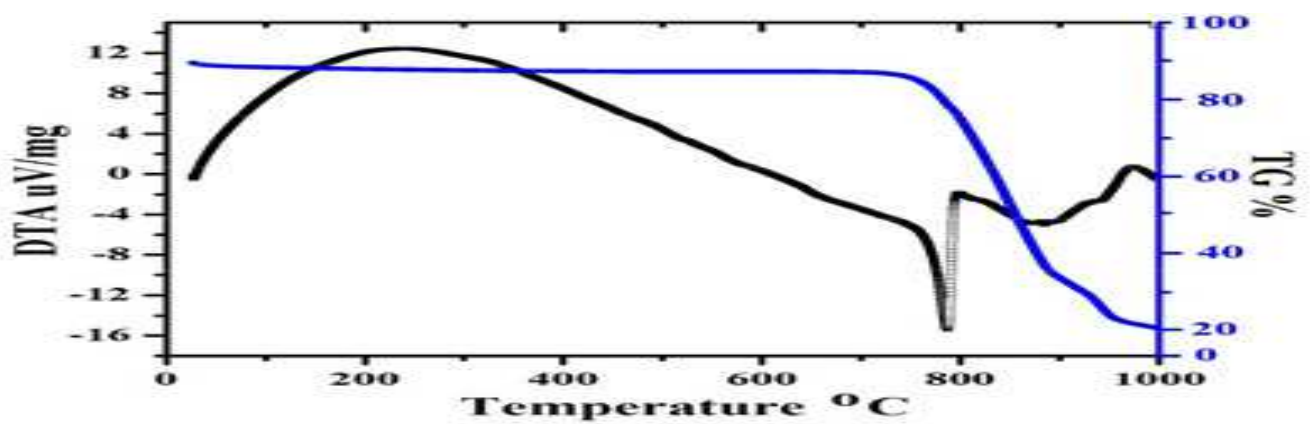

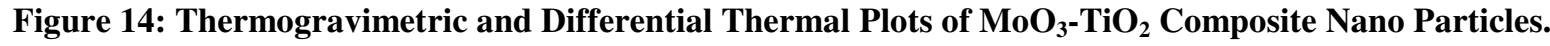

$\mathrm{MoO}_{3}-\mathrm{TiO}_{2}$ composite nano particles has a good thermal stability with a weight loss of $2.2 \%$ at $695^{\circ} \mathrm{c}$ 

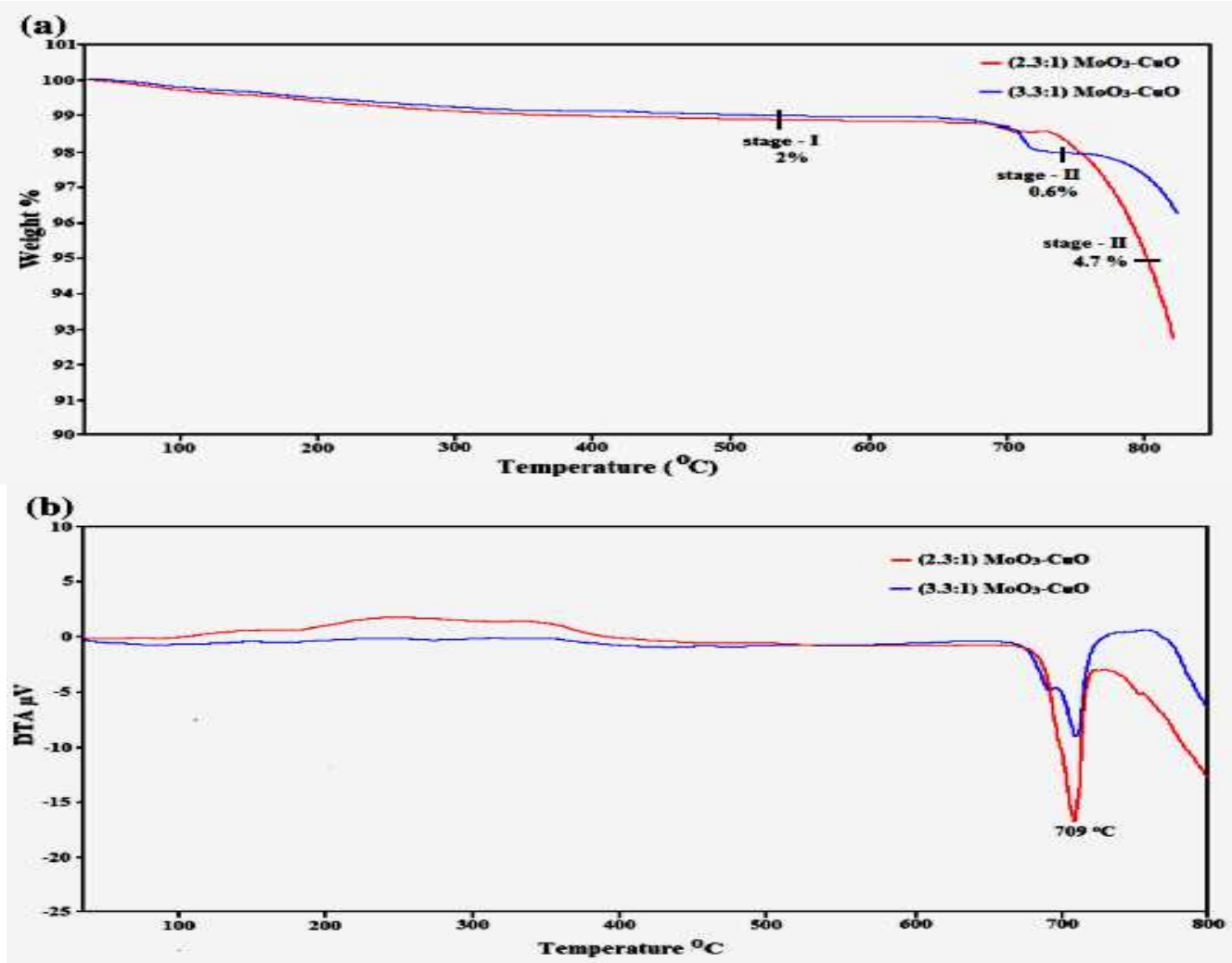

Figure 15: a) TGA Curve and b) TDA Curve of $\mathrm{MoO}_{3}-\mathrm{CuO}$ (3.3:1 and 2.3:1) Composite Nano Powders.

$\mathrm{MoO}_{3}$ and $\mathrm{CuO}$ (with weight ratios 3.3:1 and 2.3:1) nano composite powders are stable upto $710^{\circ} \mathrm{C}$ as there is a insignificant weight loss.

\section{CONCLUSIONS}

To sum up, the current experiment has been conducted in a cost - effective manner to produce $\mathrm{MoO}_{3}, \mathrm{MoO}_{3}-\mathrm{CuO}$, $\mathrm{MoO}_{3}-\mathrm{TiO}_{2}$ and $\mathrm{MoO}_{3}-\mathrm{V}_{2} \mathrm{O}_{5}$ composite nano powders for industrial commercial use. We successfully synthesized composite nanopowders using the simple and cost - effective mechanical activation method. At different times, powders were collected and the mechanical milling effect on the nano composite was performed to PXRD and no structural changes were observed with respect to the grinding/milling level. For topography study of the samples SEM analysis is important for characterizing technique and provides information about the mechanism of growth, shape and the size of particles. The TGA and DTA curves of $\mathrm{MoO}_{3}$ and $\mathrm{CuO}$ ball milled synthesized composite nano powders at 4 hours show great thermal stability to $710{ }^{0} \mathrm{C}$, as weight loss is negligible. The synthesized thermally stable $\mathrm{MoO}_{3}-\mathrm{CuO}$ nano composites are therefore suitable for use at elevated temperatures in metal insulating systems, semiconductors and solid lubricants.

\section{REFERENCES}

1. Ordonez S, Paredes JR, Diez FV (2008) J Appl. Cata. A: General, 174-180. https://doi.org/10.1016/j.apcata.2008.02.042

2. T. Vijaya Kumar, K.V. Ramana and R.B.Choudary, "Spectroscopic characterization of mechanically synthesized MoO3/TiO2 Composite Nano-powders", International Journal of Mechanical Engineering and Technology, Vol.8, Issue 5, pp.1051-1063 (2017).

3. Martinez HM, Torres J, Rodriguez-Garcia ME, Carreno LDL (2012) Phy B Condensed Matter 407:3199. https://doi.org/10. 1016/j.physb.2011.12.064 


\section{Molybdenum Trioxide and Its Nanocomposite Powders}

4. Hsu CS, Chn CC, Huang HT, Peng CH, Hsu WC (2010) J Thin Solid Films 516:4839. https://doi.org/10.1016/j.tsf.2007.09.019

5. T. Vijaya Kumar, JVS Ganesh, G. Naga Sai Krishna, "Experimental investigation on stir cast aluminum with aluminum oxide powders” , International Journal of Mechanical and Production Engineering Research and Development, Vol.8, Issue3, pp.81-88(2018)

6. Хиe QJ, Liu WM, Zhang ZJ (1997) J Wear 213:29-32. https://doi.org/10.1016/S0043-1648(97)00200-7

7. Yao JN, Hashimoro K, Fujishima A (1992) Nature 533:624-626. https://doi.org/10.1038/355624

8. T. Vijaya Kumar, G. Jayashankar, B. Srinivas, "Effect of Rolling on Hardness of Aluminum Metal Matrix Composites-An Experimental Study”, International Journal of Mechanical Engineering and Technology, Vol.8, Issue 5, pp.525-530 (2017).

9. Hamelmnn F, Gesheva K, Ivanova T, Szekeres A, Abroshev M, Heinzmnn U (2005) J Optoelectron Adv Matter, 393-399

10. T. Vijaya Kumar, K.V. Ramana "An effect of Ball Milling on microstructural parameters of nanostructured MoO3-CuO-V2O5 composite nano powders", International Journal of Mechanical and Production Engineering Research and Development, Transtellar Publishers, Vol.9, Issue 3, pp.131-142 (2019).

11. Ganguly A, George R (2007) J Mater Sci 30:183-185. https://doi.org/10.1007/s12034-007-0033-6

12. T. Vijaya Kumar, A. Gopala Krishna, Dola Sundeep, R.V.S.S.N.Ravi Kumar, "Mechanical Milling Influence on Lattice Vibrational Behavior of MoO3-V2O5 Composite Nano-powders”, Silicon Publishers, https://doi.org/10.1007/s12633-0189972-3,(2018).

13. Dong W, Hung H, Zhu Y, Li X, Wang X, Li C, Chen B, Wang G, Shi Z (2012) J Nanotechnology 23:425602. https://doi.org/10.1088/0957-4484/23/42/425602

14. Badica P (2007) J Cryst Growth Des 7:794-801. https://doi.org/10.1021/cg060893s

15. Chernova NA, Roppolo M, Dillon AC, Whittingham MS (2009) J Mater Chem 19:2526-2552. https://doi.org/10.1039/B819629J

16. Song J, Li Y, Zhu X, Zhao S, Hu Y, Hu G (2013) Mater Lett 95:190-192. https://doi.org/10.1016/j.matlet.2012.12.111

17. T. Vijaya Kumar, P. Sai Krishna, P. Uday Kumar, "Sintering of Iron powder mixtures and determining their mechanical properties Experimental investigation on stir cast aluminum with aluminum oxide powders” , International Journal of Mechanical and Production Engineering Research and Development, Vol.8, Issue 3, pp.81-88 (2018).

18. Nirupama V, Uthanna S (2010) J Mater Sci Mater Electron 21:45-52. https://doi.org/10.1007/s10854-009-9867-6

19. R.V.S.S.N.Ravi Kumar, T.Vijaya Kumar ,Dola Sundeep, A. Gopala Krishna, "Spectral Characterisation of Mechanically Synthesized MoO3-CuO Nano-Composite”, Int. Nano Lett., DOI 10.1007/s40089-015-0178-z,(2016).

20. Rao RB, Veeraiah N (2004) Physica B 348:256. https://doi.org/10. 1016/j.physb.2003.12.012

21. Chao KJ, Wu CN, Chang H, Le LJ, Hu S-f(1997) J Phys Chem B 101:6341. https://doi.org/10.1021/jp970609

22. A. Gopala Krishna, T. Vijaya Kumar, R.V.S.S.N.Ravi Kumar, Dola Sundeep, "Investigation and Comparison of Optical and Raman Bands of Mechanically Synthesized MoO3 Nano powders”, Materials Today: Proceedings 3,pp.54-63(2016).

23. Moustafa YM, El-Damrawi G, Meikhail MS (1993) Mans Sc Bull C (Nat.Sc) 20:71

24. Singh K, Ratnam JS (1988) Solid State Ion 31:221. https://doi.org/10.1016/0167-2738(88)90272-X 
25. T. Vijaya Kumar, Niranjan Reddy, Harsha. V, "Effect of Rolling on Microstructure of Aluminum Metal Matrix Composites with Magnesium Particulates-An Experimental Study”, International Journal of Mechanical Engineering and Technology, Vol.8, Issue 5, pp.583-587 (2017).

26. Wang X, Liu L, Jacobson AJ (2002) J Am Chem Soc 124:7812. https://doi.org/10.1021/ja020354l

27. Takeichi, Y., Chujyo,N. and Uemura, M., Tribology Online," Effects of Molybdenum Trioxide Properties of Aluminum Bronze under High Temperature Conditions”, 2009, 135-139.

28. Dola Sundeep,T. Vijaya Kumar, R.V.S.S.N.Ravi Kumar, A. Gopala Krishna, “ Spectral Investigation of Structural and Optical Properties of Mechanically Synthesized TiO2-V2O5 Nano-Composite Powders", Materials Today: Proceedings 3,pp.3138(2016).

29. Cullity, BD, Stock, SR; “Elements of X-ray diffraction”, (2001), 3rd ed. Prentice Hall Publication, India.

30. Vijaya Kumar, T., Ali, A., Gunasekhar, B., Rajasekhar Reddy, K., Mustafa, M.,"Experimental investigation on mechanical properties of palmyra long fibre reinforced composites”, International Journal of Innovative Technology and Exploring Engineering, vol-8, Issue-7(2019).

31. T. Vijaya Kumar, M. Indu, A. Sai Gopal, A. Vamsi Krishna, D. Venkat Reddy,” Microstructure Study and Mechanical Testing of Al 6061-Si3N4 Metal Matrix Composites”, International Journal of Innovative Technology and Exploring Engineering, vol8, Issue-9(2019).

32. J Yu, J Yang, B Liu, X Ma-Bioresource Technology,” Preparation and characterization of glycerol plasticized-pea starch/ZnO-carboxymethylcellulose sodium nanocomposites”, Bioresource Technology, Elsevier, Vol.100, Pages 28322841(2009).

33. Kumar, T. Vijaya, and K. V. Ramana. "Effect of Ball Milling on microstructural parameters of nanostructured MoO3-CuOV2O5 composite Nano powders." International Journal of Mechanical and Production Engineering Research and Development (IJMPERD) 9.3 (2019): 131-142.

34. Saber, D., Kh Abd El-Aziz, and A. Fathy. "Corrosion behavior of copper-alumina nanocomposites in different corrosive media." International Journal of Mechanical Engineering (IJME) 5.6 (2016): 1-10.

35. Sivaraj, M., et al. "The Effects of TIC Reinforcement on Thermal, Electrical and Dry Sliding Wear Behaviour of Aluminium Matrix Nanocomposites." International Journal of Mechanical and Production Engineering Research and Development (IJMPERD) 8.1 (2018):373-388

36. Bhattacharya, S. S., and S. B. Chaudhari. "Study on structural and thermal properties of polypropylene silica nanocomposite filaments." International Journal of Textile and Fashion Technology (IJTFT) 5.1 (2015): 15-22. 